to 120 miles from the land, onght according to the Challenger experiences to be occupied by "Globigerina Ooze," but so far from the theory of distribution of oceanic deposits by depth holding good in the region of the Gulf Stream, it is stated by Prof. Verrill " in other localities in 1000 to 1600 fathoms, the bottom is covered with, or largely composed of, bard, very irregular flattened crustlike concretions of clay and iron oxide."

In another station "a large number of pebbles and small rounded boulders of granite, porphyry, etc.," occurred in a depth of 2021 fathoins.

"In all our ten localities between 2000 and 3000 fathoms the bottom has been 'Globigerina Ooze.' We have never met with the 'red clay' which ought to occur at such depths according to the observations made in the cruise of the Challenger."

It is rather refreshing, after all, to find that Nature works in the sea as elsewhere, in varied ways, and that it is not as was generally supposed that monotonous waste of "ooze" and "red clay" mathematically arranged according to depth.

The Challenger work, while of enormous value. has also been in my opinion the source of many misconceptions and generalizations really unwarranted by the extent and nature of the information gathered.

Before we can accept the dictum that all sedimentary deposits arising from the settlement of matter in suspension are confined to a zone not reaching over 200 miles from the land, we must have many more dredgin ms around the continental coasts. In this excellent work of the Allatross we have, I think, evidence that ocean currents such, as the Gulf Stream, carry with them matter in suspension-and it is unreasonable to suppose that this must necessarily be all deposited within a certain limited distance from the land--its deposition being really determined by the velocity of the current. I have recently in my Presidential Address to the Liverpool Geofogical Society given my reasons for thinking that the fine argillaceous matter which is found among all the deep-sea oozes is really a mechanical deposit from the ocean waters.

It would seem to me that while every new deep-sea dredging to some extent modifies previons views, it is hardly wise to attempt to draw for all time such rigid lines of demarkation between the land and the ocean as some have lately tried to do.

\title{
IVOTIOES OF MFMOIES.
}

\section{I.-Mapoteca Geologica Americana.}

A Catalogue of Geological Maps of North and South America, in geographic and chronologic order, has just been published by the United States Geological Survey (1884). ${ }^{1}$ The work has been prepared by Messrs. Jules Marcou and J. B. Marcou.

The earliest map noted is one dated 1752, by J. E. Guettard,

1 Bulletin of the United States Geological Surver, No. 7 . 
entitled "Carte minéralogique où l'on voit la nature des terrains du Canada et de la Louisiane."

A geological map of a part of Massachusetts on Connecticut River, by E. Hitcheock (1817), is next in point of date; after which the number rapidly increases, so that no less than 924 maps are enumerated in this Catalogue, which includes all maps published to the end of 1881 .

In an introduction the authors give some account of the history of geological maps, and state that - The first geological map is due to the Abbé L. Coulon, Paris, 1664. It appeared in a little volume entitled, "Les Rivières de France," a very rare work, of which but very few copies exist in the libraries of Paris."

\section{II.-Notice of a Geological Map of Monte Somma and Vesurius. By H. J. Johnston-Lavis, F.G.S.}

VESUVIUS, using this term for the whole volcanic pile, is of all known volcanoes that one which has been most studied and written about, its phenomena more investigated than any of its rivals, and although its early history is not so complete as that of its fellows, Etna and Stromboli, yet its eruptions during the Christian Era are so intimately connected with the ill-fated cities of Pompeii, etc., and thus with archæology, that this alone is sufficient to make it most prominent.

But beyond this, its geological structure is so varied, its products so numerous, its past and present historic activity permitting the comparative study of these to be carried on, together with its convenient size and accessibility, led the author some years since to conceive the idea of minutely investigating its phenomena and structure, which it is his intention to publish in the form of a monograph and a geological map.

The two out of six sheets forming the splendid map constructed in 1876 by the students of the Italian School of Military Topography, on the large scale of $1: 10,000$ have been coloured in seven different tints, indicating the various products of different eruptive periods, ${ }^{2}$ with indications of dykes, of lateral craterets, of springs simple, or thermo-mineral, blowing caverns, buried antiquities (of geological interest), etc. The work has now extended over four suminers, and the examination of abont half, including the most complicated part of the mountain, has been completed, and the author hopes that if be is able to continue the work during the present and next summer, to finish it by the autumn of 1885. This long time occupied in the work is dependent on various causes. 1st. The great intricacy of the geology. 2nd. The thick vegetation requiring very numerous traverses. $3 \mathrm{rd}$. 'The author, for professional reasons, being only able to devote the summer months to the work; the hot Neapolitan sun of this season is so exhausting that not more than four field days a week are possible, and even then at a considerable sacrifice of health. In the two sheets exhibited

1 Brit. Assoc. Reports (Sec. C. Geology), Montreal, 1884.

2 See Memoir by the author in Quart. Journ. Geol. Soc. January, 1884. 
are a few blanks that require further study, or have been left for various reasons. The work on the other four sheets is of so scattered a nature at present that it was not thought advisable to exhibit them till in a more complete state.

Besides the actual mapping, a large amount of notes of a descriptive character have been collected, and all the important features and sections photographed on a large scale. Specimens of the various lavas, ejected blocks, tufas, pumices, etc., have been carefully selected as the work went on, so that the author has now in his possession by far the most complete geological collection from the mountain yet extant, and which are open to the study of any one who should care to investigate them.

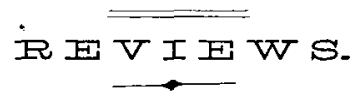

I.-The Azoic Ststem and its proposed Subnivisions. By J. D. Whitney and M. E. Wadsworth. (Bulletin of the Museum of Comparative Zoology, at Harvard College, Geological Series, Vol. I.)

THHOSE who have read Dr. Sterry Hunt's "Special Report on the Trap Dykes and Azoic Rocks of South-eastern Pennsylvania," which is in fact a résumé of the evidence on Dr. Hunt's side of the Archæan controversy, will be interested in the book before us. Prof. Whitney and Dr. Wadsworth renounce Dr. Sterry Hunt and all his works. They present the case against him with fullness and force. 'They regard most of his chief conclusions as either unsubstantial dreams or pernicious beresies. They are, in truth, as thoroughgoing in their condemnation of the modern views on Archæan Geology as Dr. Hunt is in their support. Dr. Hunt's boldness in creating hypotheses seems to have driven our authors into the extreme of scientific scepticism. This reaction is not altogether unnatural. Those who desire to take an impartial view of the Archæan controversy will anticipate that, from the strong antagonism of the disputants, there may arise a searching inquiry into the grounds on which their conclusions are based.

Dr. Hunt claims that he and his co-workers have established the existence of seven distinct terranes amongst the rocks which underlie the Cambrian. These, taken in ascending order, are as follows :-

I. LaUkentian.

II. Norian or Labradorian.

III. Arvonian.

IV. Huronian; the altered Quebec group of Logan.

V. Montalban or Mica-schist series.

VI. TAConian; the Lower Taconic of Emmons.

VII. Keweenian ; the Copper-bearing series of Lake Superior. Dr. Hunt is not certain that this group may not be roughly contemporaneous with the Taconian.

This list is an imposing one, and, if it represents the facts of nature, the range of Archæan time may well compare with that of the entire Palæozoic series, and the study of these ancient rocks becomes one of the first importance. 